$12-2005$

\title{
Pervasive Cracking of the Northern Chilean Coastal Cordillera: New Evidence for Forearc Extension
}

John P. Loveless

Cornell University, jloveles@smith.edu

Gregory D. Hoke

Cornell University

Richard W. Allmendinger

Cornell University

Gabriel González

Universidad Católica del Norte

Bryan L. Isacks

Cornell University

See next page for additional authors

Follow this and additional works at: https://scholarworks.smith.edu/geo_facpubs

Part of the Geology Commons

\section{Recommended Citation}

Loveless, John P.; Hoke, Gregory D.; Allmendinger, Richard W.; González, Gabriel; Isacks, Bryan L.; and Carrizo, Daniel A., "Pervasive Cracking of the Northern Chilean Coastal Cordillera: New Evidence for Forearc Extension" (2005). Geosciences: Faculty Publications, Smith College, Northampton, MA.

https://scholarworks.smith.edu/geo_facpubs/12

This Article has been accepted for inclusion in Geosciences: Faculty Publications by an authorized administrator of Smith ScholarWorks. For more information, please contact scholarworks@smith.edu 
Authors

John P. Loveless, Gregory D. Hoke, Richard W. Allmendinger, Gabriel González, Bryan L. Isacks, and Daniel A. Carrizo 
Loveless et al.

G22004

Page 1 of 15

\title{
Pervasive cracking of the northern Chilean Coastal
}

\section{Cordillera: New evidence for forearc extension}

John P. Loveless

Gregory D. Hoke

Richard W. Allmendinger

Department of Earth and Atmospheric Sciences, Cornell University, Snee Hall, Ithaca, NY 14853, USA

Gabriel González

Departamento de Ciencias Geológicas, Universidad Católica del Norte, Casilla 1280, Antofagasta, Chile

Bryan L. Isacks

Department of Earth and Atmospheric Sciences, Cornell University, Snee Hall, Ithaca, NY 14853, USA

\section{Daniel A. Carrizo}

Departamento de Ciencias Geológicas, Universidad Católica del Norte, Casilla 1280, Antofagasta, Chile

\begin{abstract}
Despite convergence across the strongly coupled seismogenic interface between the South American and Nazca plates, the dominant neotectonic signature in the forearc of northern Chile is arc-normal extension. We have used 1-m resolution IKONOS satellite imagery to map nearly 37,000 cracks over an area of $500 \mathrm{~km}^{2}$ near the Salar Grande $\left(21^{\circ} \mathrm{S}\right)$. These features, which are best preserved in a ubiquitous gypcrete surface
\end{abstract}


Loveless et al.

G22004

Page 2 of 15

layer, have both nontectonic and tectonic origins. However, their strong preferred orientation perpendicular to the plate convergence vector suggests that the majority owe their formation to approximate east-west extension associated with plate boundary processes such as interseismic loading, co- and postseismic strain, and long-term instability resulting from subduction erosion. Similar structures were formed during or shortly after the $1995 M_{w}=8.0$ earthquake near the city of Antofagasta, south of Salar Grande, and in conjunction with the $2001 M_{w}=8.2-8.4$ Arequipa, Peru, event. Cracks such as these may form in other forearcs but remain largely unexposed because of vegetative cover or marked fluvial erosion - factors that are absent in northern Chile as a result of its hyperarid climate.

Keywords: Northern Chile, forearc, subduction zones, neotectonics INTRODUCTION

As the Nazca plate subducts beneath South America, strong coupling between the two plates from $\sim 20$ - to 50-km depth (Tichelaar and Ruff, 1991) allows for the accumulation of elastic strain in the overriding continent (Klotz et al., 1999; Bevis et al., 2001). However, no structures in the forearc indicate permanent arc-normal shortening resulting from such loading. Instead, many features demonstrate extension nearly parallel to the direction of convergence. Approximately north-south-striking normal faults are observed both off- and onshore (Arabasz, 1971; Delouis et al., 1998; von Huene et al., 1999; González et al., 2003; von Huene and Ranero, 2003). Displacement on normal faults is primarily dip-slip (Delouis et al., 1998), suggesting an extension nearly perpendicular to the fault strike. Most faults are mapped as steeply landward dipping 
Loveless et al.

G22004

Page 3 of 15

(Arabasz, 1971; Delouis et al., 1998), although dips as low as $45^{\circ}$ have been documented on the Mejillones Peninsula ( 23.5 S latitude, González et al., 2003).

In addition to these well-known normal faults, mode 1 (opening) cracks are present in the forearc (González et al., 2003). We describe here a dense suite of cracks west of Salar Grande, located in the Chilean Coastal Cordillera near $21^{\circ} \mathrm{S}$ latitude (Figs. 1 and 2). Through mapping of a 500- $\mathrm{km}^{2}$ area by high-resolution IKONOS imagery and fieldwork, we find a consistent crack orientation normal to the direction of plate convergence. The regularity in strike and broad distribution imply a genetic relationship between cracks and plate boundary processes. We discuss the origins of the cracks and suggest that they are driven primarily by tectonic processes.

\section{TECTONIC SETTING}

Over the past $25 \mathrm{Ma}$, convergence between the Nazca and South American plates across a strongly coupled plate interface has resulted in crustal shortening and thickening, giving rise to the modern Andes. Great interplate thrust earthquakes $(M \geq 8)$ are thought to rupture individual segments of the margin with recurrence intervals of $\sim 100-150 \mathrm{yr}$ (Comte and Pardo, 1991). The southern Peru segment ( $16^{\circ}$ to $\left.18^{\circ} \mathrm{S}\right)$ ruptured in 2001 , partially filling the post-1868 seismic gap, and the segment immediately south of the Mejillones Peninsula $\left(\sim 23^{\circ} \mathrm{S}\right)$ ruptured in 1995 (Fig. 1). The $\sim 420$-km-long segment of northernmost Chile last experienced a great earthquake in 1877, the epicenter of which was estimated at $21.00^{\circ} \mathrm{S}, 70.25^{\circ} \mathrm{W}$, just offshore of Salar Grande (Fig. 1; Comte and Pardo, 1991).

GPS data show orogen-scale interseismic shortening of the Central Andes in the direction of plate convergence on decadal timescales (Fig. 1; Bevis et al., 2001). The 
Loveless et al.

G22004

Page 4 of 15

velocity field has been modeled by using an elastic half-space with dislocations applied to the plate boundary that is locked between depths of 20 and $50 \mathrm{~km}$ during interseismic times (Klotz et al., 1999; Bevis et al., 2001). This model for the plate boundary is consistent with the conclusions of Tichelaar and Ruff (1991), who used seismic waveform inversion to analyze the variation in degree and extent of coupling along the Chilean margin.

GPS (Klotz et al., 1999) and interferometric radar (Pritchard et al., 2002) data spanning the $1995 M_{w}=8.0$ Antofagasta earthquake show a coseismic surface displacement gradient opposite that of the interseismic velocity field of northern Chile (Fig. 1). The increase in westward displacement (relative to stable South America) from east to west shows that the Coastal Cordillera was extended during this earthquake. Surface cracking and 15-20 cm of normal fault slip occurred during the event (Delouis et al., 1998; González et al., 2003), consistent with the coseismic strain captured by geodetic measurements. Delouis et al. (1998) proposed that other fresh-looking fault scarps in this region also developed as secondary features related to Quaternary subduction earthquakes. Near the coastal city of Ilo, southern Peru, substantial ground cracking and landslides accompanied the $2001 M_{w}=8.1$ Arequipa earthquake. These cracks are thought to be coseismically reactivated features that initially formed during the great 1604 earthquake that originated near Ilo (Keefer and Moseley, 2004).

The bedrock of the Coastal Cordillera represents the remnant of a Late JurassicEarly Cretaceous magmatic arc. Original arc structures such as the Atacama Fault Zone influence neotectonic deformation (Arabasz, 1971). The presence of a Mesozoic arc remnant so close to the modern trench suggests long-term tectonic removal and 
Loveless et al.

G22004

Page 5 of 15

subduction of material at the trench (subduction erosion), causing $\sim 1 \mathrm{~km} / \mathrm{Ma}$ of trench retreat (Rutland, 1971; von Huene and Scholl, 1991). This tectonic erosion and underplating of subducted material beneath the Coastal Cordillera may cause uplift and extension (von Huene et al., 1999; von Huene and Ranero, 2003).

\section{CRACKS IN THE SALAR GRANDE REGION}

We focus our study of cracks on a region located at $\sim 21^{\circ} \mathrm{S}$ latitude between the Salar Grande and the Pacific Ocean (Fig. 2). The study area is located within the hyperarid Atacama Desert and is perched atop the 400-1200-m-high coastal escarpment of northern Chile. The persistence of the dry climatic conditions for at least $6 \mathrm{Ma}$ (Hartley and Chong, 2002) and consequent preservation of landforms allow us to use present topography as a proxy for neotectonic deformation.

Cracks in the Salar Grande region are best preserved in the gypsum-indurated gravel (gypcrete) that blankets large areas of coastal northern Chile, but they also penetrate as deep as $8 \mathrm{~m}$ into bedrock. The latter are commonly parallel to bedrock joint sets, suggesting that some bedrock joints have propagated through the gypcrete. Surface cracks showing no correlation to bedrock joints are also present. Cracks are less evident in nonindurated sediments, indicating that characteristics of the gypcrete enhance preservation of the structures. Some cracks have been sealed by precipitated gypsum, but most are open. Vertical offset of up to $1 \mathrm{~m}$ is observed in a few locations; we suggest that most cracks are mode 1, but some mixed-mode cracks also exist. Apertures range from a few centimeters to $2.5 \mathrm{~m}$, with many on the order of $0.5 \mathrm{~m}$. Erosion of the gypcrete modifies crack morphology, rounding initially sharp edges and transporting wall material to the crack base. Fault scarp and crack morphologies, crack interaction patterns, and 
Loveless et al.

G22004

Page 6 of 15

variation in aperture and depth give insight into relative ages of structures, but because material diffusion constants are unknown in the Atacama Desert, absolute dating is not possible.

Remote sensing and field-based observations allow us to divide cracks into two groups: those with nontectonic origins, and those likely formed by tectonic processes.

\section{Nontectonic Cracks}

Cracks with millimeter- to centimeter-scale apertures commonly connect to form polygonal shapes centimeters to meters across within the gypsum- or locally haliteindurated gravel. This patterned ground probably formed by shrinking and swelling that resulted from fluctuations in temperature and moisture content (Tucker, 1978). The thick fog that blankets much of coastal northern Chile, particularly during the winter, is the source of both the gypsum (Rech et al., 2003) and moisture. Because cracks of this type are generally too small to detect by means of remote sensing, they have not been considered in our statistical analyses or measurements of regional strain. Locally, hillsides of cracked, 1-2-m-thick layers of gypcrete are delimited by a lobelike front, suggesting some downslope movement of gypcrete layers. The cracks in these areas parallel topographic contours, suggesting that gravitational forces are responsible for their formation.

\section{Tectonic Cracks}

The nonuniform strikes and isolated occurrences of the nontectonic features described above contrast the strong preferred orientation and broad distribution of the cracks observed through remote sensing. We used IKONOS satellite imagery, which offers 1-m spatial resolution in the panchromatic band, to map more than 37,000 cracks 
Loveless et al.

G22004

Page 7 of 15

over $500 \mathrm{~km}^{2}$ (Fig. 2). The mapped structures have consistent strike, with a lengthweighted mean azimuth of $347^{\circ}$ (circular variance of 0.21 ), which is similar to the trends of both the coastline and plate boundary and which is perpendicular to the plate convergence vector (Fig. 2E).

Many cracks cluster spatially around mapped fault scarps (Fig. 2A-E); faults and cracks have similar, but not identical, orientations (mean strikes of $325^{\circ}$ and $347^{\circ}$, respectively; Fig. 2E, F). Near the Hombre Muerto fault (Fig. 2A), for example, narrow, shallow cracks of regional extent are oriented oblique to the fault scarp. With decreasing distance to the scarp, crack aperture and depth increase, reaching maxima at the scarp crest. In general, crack formation may precede faulting, but continued propagation of the cracks likely occurs as a secondary response to fault slip. In some cases, faults seem to have perturbed the stress field in which the cracks propagate, causing curvature of strike near the fault (Fig. 2B, C). Such perturbations can result from asperities that concentrate stress on the fault surface (Rawnsley et al., 1992).

\section{Quantification of Extension}

To determine the magnitude of finite extension represented by cracks in the imagery, we counted cracks intersecting transects trending perpendicular to the mean strike. Strain values along transects measured in the field were used to calibrate average crack aperture in the imagery-based profiles, allowing a simple count of cracks to roughly estimate extension magnitude. Along transects crossing the entire IKONOS data set, extension values reach $\sim 1.25 \%$. Adjacent to faults, greater calculated extension of $5 \%-$ $10 \%$ (over several hundred meters) is consistent with the observations of crack concentration around faults. 
Loveless et al.

G22004

Page 8 of 15

\section{DISCUSSION}

The documented coseismic extension from field observations (Delouis et al., 1998) and GPS measurements (Klotz et al., 1999) of the 1995 Antofagasta earthquake provide evidence that extensional structures deform during or shortly after earthquakes. The displacement gradient tensor determined from the 1995 GPS data indicates maximum extensional strain of $8.93 \times 10^{-4} \%$ along an azimuth N63E. Salar Grande lies well north of Antofagasta, but we compare effects of the 1995 event to the cracks we have described because no great earthquake has occurred in northernmost Chile since 1877. The discrepancy between GPS-based and our crack-based strain estimates is several orders of magnitude, indicating that strain accompanying one great earthquake is insufficient to explain the cracking. Cracks may represent extension associated with many earthquakes, a possibility supported by field observations of repeated opening and filling of cracks. If crack propagation occurs only during and/or shortly after earthquakes, we estimate, on the basis of the comparisons above, that $\sim 1 \times 10^{3}$ great earthquakes would be required to account for the finite extension. Given the 100-150-yr recurrence interval of Comte and Pardo (1991), this number of events has occurred over the past 100-150 ka. Although the climatic conditions of the Coastal Cordillera may preserve features of this age, we suggest that other sources of strain, such as interseismic loading and subduction erosion, also contribute to crack propagation, decreasing the time span represented by the structures.

Our simple dislocation models of interseismic loading (based on Okada, 1985) predict that coastal regions of a simulated Andean margin with a plate boundary locked between depths of 20 and $50 \mathrm{~km}$ experience $\sim \mathrm{E}-\mathrm{W}$ extensional strain on the order of $1 \times$ 
Loveless et al.

G22004

Page 9 of 15

$10^{-3} \%$. GPS stations are spaced such that they do not capture this narrow longitudinal zone of extension. This magnitude of strain is about equal to that demonstrated by the coseismic GPS data and is applied over a much longer time period (100 yr), yielding lower strain rates. The sense of predicted interseismic strain is similar to that due to the Antofagasta earthquake. This seems counterintuitive but results from different loading geometries: interseismic strain accumulation presumably occurs across the entire extent of the locked plate interface, whereas the Antofagasta earthquake ruptured only a portion of the fault. The dimensions of slip on the subduction thrust directly affect the surface deformation. The interseismic strain may itself cause brittle deformation of the forearc, or it may precondition the region for failure when more rapid coseismic strains are applied, as proposed by Delouis et al. (1998).

Long-term extension and uplift associated with subduction erosion processes have also been proposed as mechanisms for normal faulting in the forearc (Delouis et al., 1998; von Huene and Ranero, 2003). Gravitational instability induced by the removal of material at the toe of the continental slope leads to extensional failure of the slope and forearc, demonstrated by normal faults observed offshore (von Huene and Ranero, 2003). Additionally, underplating of subduction-eroded material may contribute to uplift and surface extension of the forearc (Delouis et al., 1998).

Dynamic stresses accompanying shear rupture propagation during great earthquakes may also generate mode 1 surface cracks. Dalguer et al. (2003) indicate that cracks formed by this mechanism are characterized by branched ends, which we do not observe in the Salar Grande region. Savalli and Engelder (2005) suggest that static, subcritical joint propagation is the most prominent mechanism of crack development in 
Loveless et al.

G22004

Page 10 of 15

Earth's crust. Subcritical propagation, or crack growth that occurs even though the stress intensity at the tips is less than the critical level predicted by fracture mechanics, can occur as a result of fluid and/or chemical activity that facilitate crack propagation (Atkinson and Meredith, 1987). Segall (1984) states that strains applied continuously cause crack growth, whereas the material response to loads that fluctuate rapidly in magnitude may be elastic and thus not conducive to crack growth, even if critical stress intensity conditions are met. Therefore, static loading from interseismic convergence, subduction erosion processes, and co- and postseismic phenomena is the likely mechanism for crack propagation in the Salar Grande region, with dynamic shear rupture during earthquakes playing a lesser role.

The plate boundary-scale interseismic loading and regional seismicity suggest that cracks similar to those seen at Salar Grande and Ilo, Peru, should be distributed throughout the forearc, yet we have not observed such concentrations in our reconnaissance visits to other locations, which suggests that the Salar Grande and Ilo regions are anomalous. The elevated concentration of faults (Yu and Isacks, 1999) and several bedrock joint sets near Salar Grande demonstrate weakness in the uppermost crust that locally allows surface cracking when tectonically loaded. Additionally, because the degree of gypsum induration of the sediment cover dictates the quality of crack preservation, variations in surface composition could help to explain the different concentrations of cracks in the forearc. Gypcrete covers a substantial portion of the Coastal Cordillera, but its material properties around our study area may enhance preservation of cracks. It is likely that cracks similar to those we describe here are present in other forearcs but may not be observed because of rapid landscape modification under 
wetter climatic conditions. The unique, hyperarid environment of northern Chile has literally laid bare the true extent of brittle deformation.

\section{ACKNOWLEDGMENTS}

We thank F. Gomez, G. Depine, H. Caprio, and F. Aron for valuable discussion and assistance in the field. Thoughtful reviews by T. Engelder, G. Hilley, and an anonymous referee greatly improved the article. This research is supported by National Science Foundation grants EAR-0087431 and EAR-0337496 (to RWA), National Aeronatics and Space Administration (NASA) grant NAG5-11424 (to BLI), NASA Earth System Science fellowships (to JPL and GDH), and Fondo Nacional De Desarrollo Cientifico Y Tecnologico Chile grant 1040389 (to GG).

\section{REFERENCES CITED}

Arabasz, W.J., Jr., 1971, Geological and geophysical studies of the Atacama fault zone, in northern Chile [Ph.D. thesis]: Pasadena, California Institute of Technology, $275 \mathrm{p}$.

Atkinson, B.K., and Meredith, P.G., 1987, The theory of subcritical crack growth with applications to minerals and rocks, in Atkinson, B.K., ed., Fracture mechanics of rock: London, Academic Press, p. 111-166.

Bevis, M., Kendrick, E., Smalley, R., Jr., Brooks, B., Allmendinger, R.W., and Isacks, B.L., 2001, On the strength of interplate coupling and the rate of back arc convergence in the central Andes: An analysis of the interseismic velocity field: Geochemistry, Geophysics, Geosystems, v. 2, [[AU: Please supply page numbers.]]doi:10.1029/2001GC000198. 
Loveless et al.

G22004

Page 12 of 15

Comte, D., and Pardo, M., 1991, Reappraisal of great historical earthquakes in the northern Chile and southern Peru seismic gaps: Natural Hazards, v. 4, p. 23-44, doi: 10.1007/BF00126557.

Dalguer, L.A., Irikura, K., and Riera, J.D., 2003, Simulation of tensile crack generation by three-dimensional dynamic shear rupture propagation during an earthquake: Journal of Geophysical Research, v. 108, p. 2144, doi: 10.1029/2001JB001738, doi: 10.1029/2001JB001738.

Delouis, B., Philip, H., Dorbath, L., and Cisternas, A., 1998, Recent crustal deformation in the Antofagasta region (northern Chile) and the subduction process: Geophysical Journal International, v. 132, p. 302-338, doi: 10.1046/j.1365-246x.1998.00439.x.

González, G., Cembrano, J., Carrizo, D., Macci, A., and Schneider, H., 2003, The link between forearc tectonics and Pliocene-Quaternary deformation of the Coastal Cordillera, northern Chile: Journal of South American Earth Sciences, v. 16, p. 321342, doi: 10.1016/S0895-9811(03)00100-7.

Hartley, A.J., and Chong, G., 2002, Late Pliocene age for the Atacama Desert: Implications for the desertification of western South America: Geology, v. 30, p. 4346, doi: 10.1130/0091-7613(2002)030<0043:LPAFTA>2.0.CO;2.

Keefer, D.K., and Moseley, M.E., 2004, Southern Peru desert shattered by the great 2001 earthquake: Implications for paleoseismic and paleo-El Niño-Southern Oscillation records: Proceedings of the National Academy of Sciences of the United States of America, v. 101, p. 10878-10883, doi: 10.1073/pnas.0404320101.

Klotz, J., Angermann, D., Michael, G.W., Porth, R., Reigber, C., Reinking, J., Viramonte, J., Perdomo, R., Rios, V.H., Barrientos, S., Barriga, R., and Cifuentes, O., 1999, 
Loveless et al.

G22004

Page 13 of 15

GPS-derived deformation of the Central Andes including the 1995 Antofagasta $M_{w}=$ 8.0 earthquake: Pure and Applied Geophysics, v. 154, p. 709-730, doi:

$10.1007 / \mathrm{s} 000240050249$.

Okada, Y., 1985, Surface deformation due to shear and tensile faults in a half-space:

Bulletin of the Seismological Society of America, v. 75, p. 1135-1154.

Pritchard, M.E., Simons, M., Rosen, P.A., Hensley, S., and Webb, F.H., 2002, Coseismic slip from the 1995 July $30 M_{w}=8.1$ Antofagasta, Chile, earthquake as constrained by InSAR and GPS observations: Geophysical Journal International, v. 150, p. 362-376, doi: 10.1046/j.1365-246X.2002.01661.x.

Rawnsley, K.D., Rives, T., Petit, J.-P., Hencher, S.R., and Lumsden, A.C., 1992, Joint development in perturbed stress fields near faults: Journal of Structural Geology, v. 14, p. 939-951, doi: 10.1016/0191-8141(92)90025-R.

Rech, J.A., Quade, J., and Hart, W.S., 2003, Isotopic evidence for the source of Ca and S in soil gypsum, anhydrite and calcite in the Atacama Desert, Chile: Geochimica et Cosmochimica Acta, v. 67, p. 575-586, doi: 10.1016/S0016-7037(02)01175-4.

Rutland, R.W.R., 1971, Andean orogeny and ocean floor spreading: Nature, v. 233, p. $252-255$.

Savalli, L., and Engelder, T., 2005, Mechanisms controlling rupture shape during subcritical growth of joints in layered rocks: Geological Society of America Bulletin, v. 117, p. 436-449, doi: 10.1130/B25368.1.

Segall, P., 1984, Rate-dependent extensional deformation resulting from crack growth in rock: Journal of Geophysical Research, v. 89, p. 4185-4195. 
Loveless et al.

G22004

Page 14 of 15

Tichelaar, B.W., and Ruff, L.J., 1991, Seismic coupling along the Chilean subduction zone: Journal of Geophysical Research, v. 96, p. 11,997-12,022.

Tucker, M.E., 1978, Gypsum crusts (gypcrete) and patterned ground from northern Iraq: Zeitschrift für Geomorphologie, v. 22, p. 89-100.

von Huene, R., and Ranero, C.R., 2003, Subduction erosion and basal friction along the sediment-starved convergent margin off Antofagasta, Chile: Journal of Geophysical Research, v. 108, p. 2079, doi: 10.1029/2001JB001569, doi: 10.1029/2001JB001569. von Huene, R., and Scholl, D.W., 1991, Observations at convergent margins concerning sediment subduction, subduction erosion, and the growth of continental crust: Reviews of Geophysics, v. 29, p. 279-316.

von Huene, R., Weinrebe, W., and Heeren, F., 1999, Subduction erosion along the North Chile margin: Journal of Geodynamics, v. 27, p. 345-358, doi: 10.1016/S0264$3707(98) 00002-7$

Yu, J.S., and Isacks, B.L., 1999, Examination of the surface expression of the Atacama fault system in northern Chile from interferometrically derived (INSAR) topography: Eos (Transactions, American Geophysical Union), v. 80, p. 1060.

Figure 1. Seismotectonic setting of northern Chile and southern Peru. Gradients in interseismic GPS velocities (vector scale I; from Bevis et al., 2001) and coseismic displacements (vector scale C; from Klotz et al., 1999) demonstrate shortening and extension, respectively. Epicenters of great earthquakes are shown as black dots; 
Loveless et al.

G22004

Page 15 of 15

approximate rupture areas are enclosed by ellipses (2001 rupture area outlined with dashed line). Box near Salar Grande shows area of Figure 2.

Figure 2. Crack mapping in Salar Grande region. (A) Morphological features and cracks mapped using IKONOS imagery. Numerous cracks (black lines) cluster around faults (gray lines), but this relationship is not unique. HM-Hombre Muerto fault. (B) Detail of crack mapping near two fault scarps. (C) IKONOS satellite image showing clusters of cracks around fault scarps in region of B). (D) Field photograph of cracks parallel to fault scarps. Road in center of photo is $\sim 2 \mathrm{~m}$ wide. (E, F) Rose diagrams showing strike distribution of cracks (E) and faults in Salar Grande region (F), with length-weighted mean orientation and direction of relative plate convergence (PC) indicated by arrows. 


\section{Loveless Fig. 1}

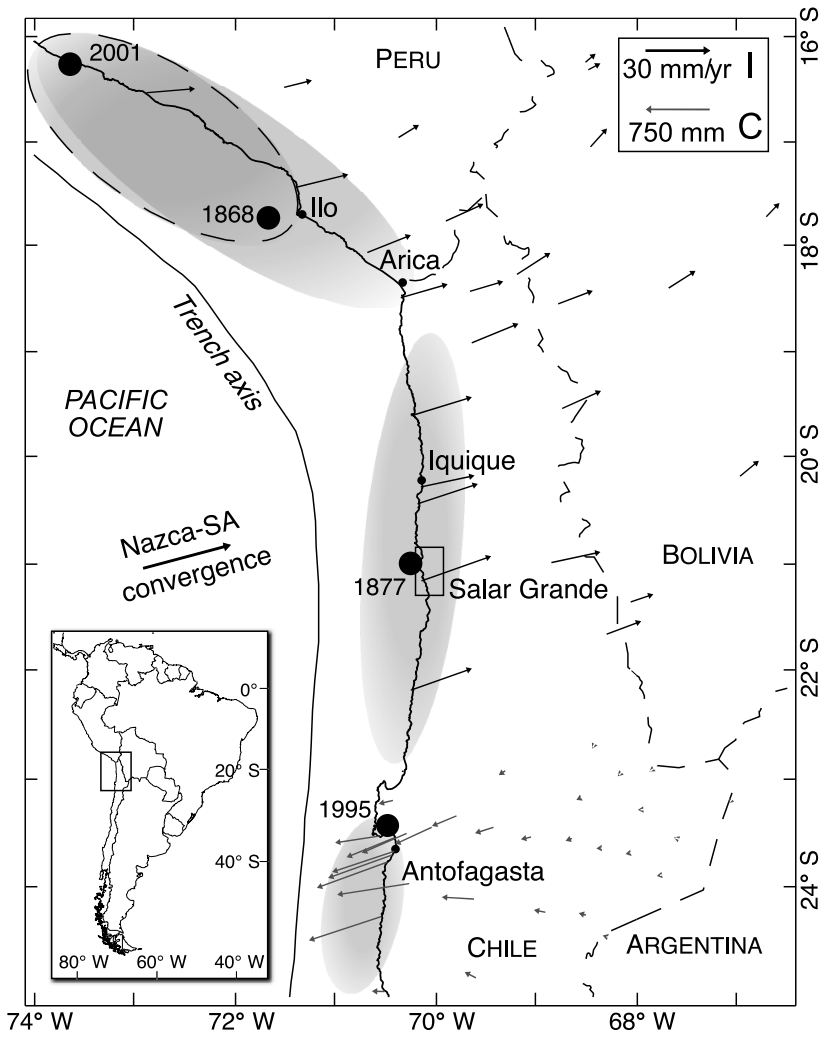


Loveless Fig. 2

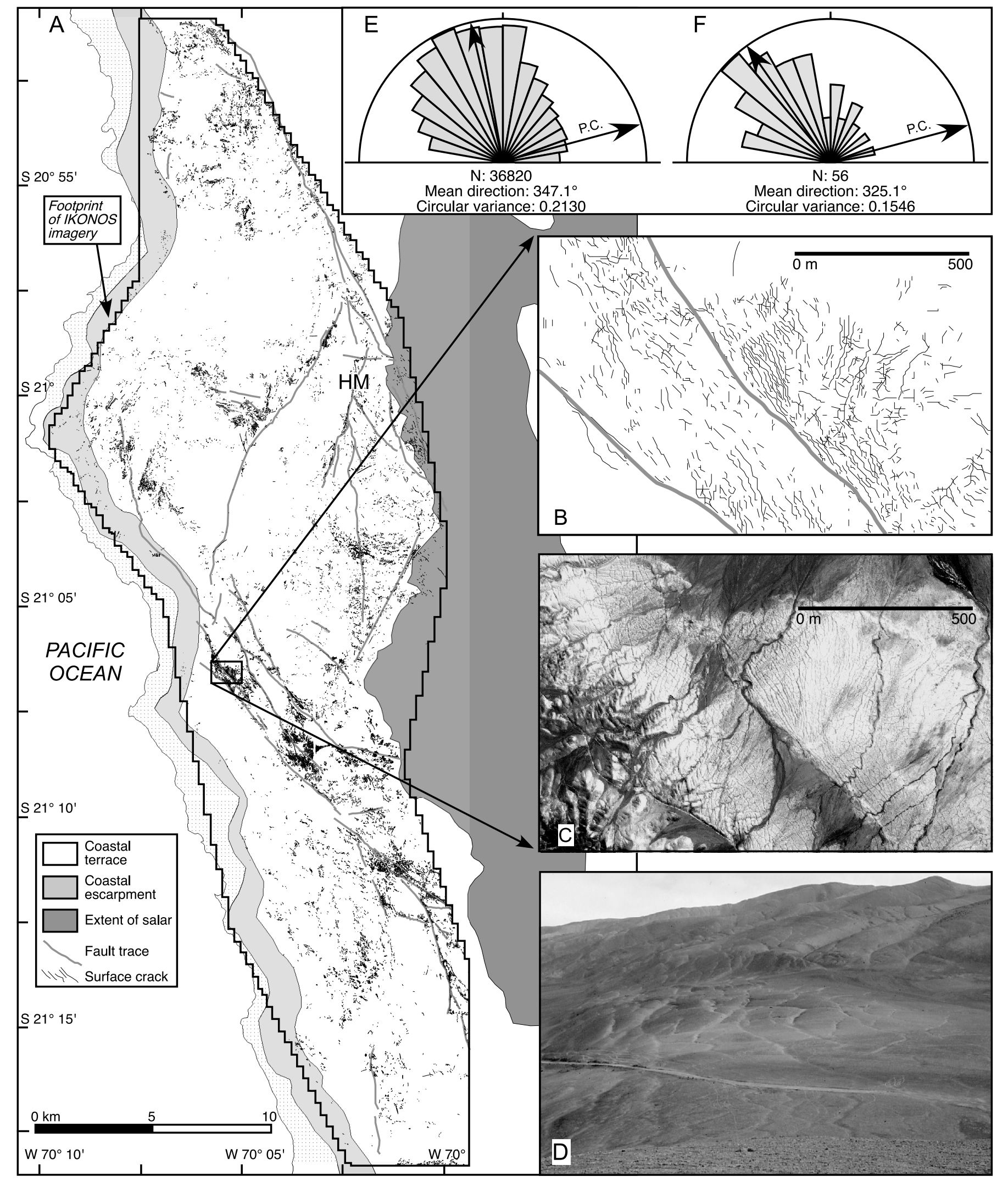

